\title{
Thermal decomposition of chrysotile-containing wastes in a water vapor atmosphere
}

\author{
Takahiro KOZAWA, Ayumu ONDA, Kazumichi YANAgISAWA, ${ }^{\dagger}$ Osamu CHIBA, ${ }^{*}$ \\ Hiroyuki ISHIWATA ${ }^{* *}$ and Tetsuro TAKANAMI*** \\ Research Laboratory of hydrothermal Chemistry, Faculty of Science, Kochi University, 2-5-1 Akebono-cho, Kochi 780-8520 \\ ${ }^{*}$ Technical Research Institute, Toda Co., 1-7-1 Kyobashi, Chuo-ku, Tokyo 104-8388 \\ ${ }^{* * *}$ Technical Research Institute, Nishimatsu Construction Co., Ltd., 1-20-10 Toranomon, Minato-ku, Tokyo 105-8401 \\ *** Division of Environmental Engineering, Daioh Shinyo Co., Ltd., 5-5 Ekimae-cho, Kochi 780-8553
}

\begin{abstract}
A simple thermal decomposition technique to convert asbestos-containing wastes (ACWs) into non-asbestos products has been developed by heating ACWs in a water vapor atmosphere. It was confirmed that cement slates containing 18 mass $\%$ chrysotile were converted into non-asbestos products by the thermal treatment in a water vapor atmosphere at $800^{\circ} \mathrm{C}$ for $2 \mathrm{~h}$. In contrast, the thermal treatments in air required temperatures as high as $900^{\circ} \mathrm{C}$ to convert the cement slates into non-asbestos products. It should be noted that any chrysotile particles were not detected by the phase-contrast microscopic observation in the products after the thermal treatments in a water vapor atmosphere at temperatures beyond $800^{\circ} \mathrm{C}$ but three or less chrysotile particles remained after the thermal treatments in air at high temperatures beyond $900^{\circ} \mathrm{C}$. In a water vapor atmosphere, ACWs were successfully converted into non-asbestos products at low temperatures below $800^{\circ} \mathrm{C}$ for $2 \mathrm{~h}$ by accelerated solid-state reactions between decomposed products of chrysotile and cement components to form calcium magnesium silicates. This technique may contribute to large-scale decomposition of ACWs with low energy consumption in comparison with the traditional melting method.

(C2010 The Ceramic Society of Japan. All rights reserved.
\end{abstract}

Key-words : Chrysotile, Chrysotile-containing wastes, Asbestos, Water vapor, Thermal decomposition, Detoxification

[Received June 22, 2010; Accepted September 16, 2010]

\section{Introduction}

Since the melting treatment is the only allowed method in Japan as an intermediate treatment to convert asbestos-containing wastes (ACWs) into non-asbestos products, a number of approaches for decomposition of asbestos and ACWs have been reported. Fujishige et al. ${ }^{1)-3)}$ found that the addition of calcium carbonate and chloride to asbestos or ACWs produced a melt at low temperatures and consequently lowered the decomposition temperatures of asbestos. The addition of calcium chloride, however, may cause the restraint in the recycle of the decomposed products. In our previous paper, chrysotile $\left(\mathrm{Mg}_{3} \mathrm{Si}_{2} \mathrm{O}_{5}(\mathrm{OH})_{4}\right)$ was decomposed at $150^{\circ} \mathrm{C}$ by the solid-gas reaction with acidic gas ( $\mathrm{HF}$ and $\mathrm{HCl}$ ) which was generated from the decomposition of Freon. ${ }^{4)}$ Although ACWs were converted by this technique to non-asbestos products at low temperatures, it is difficult to recycle the decomposed products mainly consisting of fluorides.

Asbestos minerals are naturally occurring magnesium silicate hydroxides, so that they decompose to release water by heating at high temperatures. It is reported that chrysotile is decomposed into non-hazardous substances at temperatures from 500 to $800^{\circ} \mathrm{C}^{5), 6)}$ Hashimoto et al. ${ }^{7-12)}$ have proposed a two step decomposition technique of ACWs including calcination at low temperatures below $1000^{\circ} \mathrm{C}$ and subsequent mechanical grinding. The pure chrysotile fiber was almost decomposed to the amorphous phase by heating at $600^{\circ} \mathrm{C}$ for $3 \mathrm{~h}$ in air and the fibrous structure was destroyed by subsequent grinding treatments. ${ }^{7)}$ In the case of chrysotile-containing cement boards, ${ }^{8,9)}$ the cement boards could be easily ground after heating at $600^{\circ} \mathrm{C}$ for $2 \mathrm{~h},{ }^{8)}$ but

Corresponding author: K. Yanagisawa; E-mail: yanagi@kochi-u. ac.jp the thermal treatment at $800^{\circ} \mathrm{C}$ for $2 \mathrm{~h}$ was required to judge the treated products as non-asbestos based on Japanese Industrial Standard (JIS A 1481:2006), ${ }^{9), 13)}$ using powder X-ray diffraction (XRD) and PCM analyses. This two step decomposition technique requires large-scale grinding equipments, and the thermal treatment in air has an anxious problem. It was reported that a few chrysotile fibers were detected by PCM in the product obtained by the thermal treatment of pure chrysotile at $1000^{\circ} \mathrm{C}$ for $3 \mathrm{~h}$ when the product was observed without grinding. ${ }^{14)}$

Generally, the decomposed products of asbestos minerals react with other substances by solid-state reactions during the thermal treatment of ACWs. ${ }^{9), 10), 12), 15)}$ Recently, we have found that the solid-state reactions to form $\beta$-dicalcium silicate $\left(\beta-\mathrm{Ca}_{2} \mathrm{SiO}_{4}\right)$ and barium titanate $\left(\mathrm{BaTiO}_{3}\right)$ were accelerated by water vapor. ${ }^{16), 17)}$ Therefore, it is expected that the thermal treatment of ACWs in a water vapor atmosphere can convert ACWs into non-asbestos products at lower temperatures by accelerated solid-state reactions. Thus, the aim of this research is to investigate the feasibility of the thermal decomposition of ACWs including chrysotile into non-asbestos products in a water vapor atmosphere.

\section{Experimental}

In this study, chrysotile-containing corrugated plates were used as ACWs. Chrysotile content was determined to be 18 mass \% by using the quantitative XRD analysis at a public institution. For the sake of shorthand, the corrugated plates were denoted as ACW18. In addition to chrysotile, ACW18 mainly consisted of calcite $\left(\mathrm{CaCO}_{3}\right)$ and a small amount of quartz $\left(\mathrm{SiO}_{2}\right)$. The crystalline phases of hydration products of cement could not be identified because of their low crystallinity. The thermal decomposition of ACW18 (about $1 \mathrm{~cm} \times 1 \mathrm{~cm}$ and $0.5 \mathrm{~cm}$ in thickness, $0.5 \mathrm{~g}$ each) was heated at various temperatures for $2 \mathrm{~h}$ in air and a water vapor 

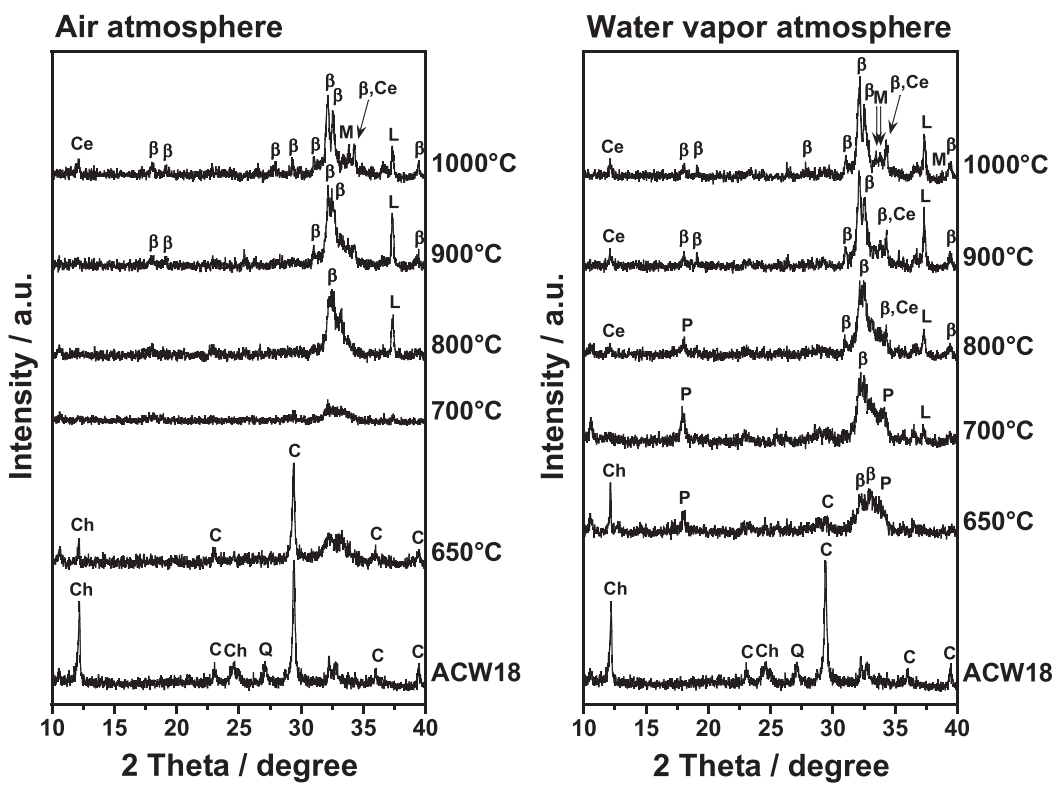

Fig. 1. XRD patterns of the ACW18 and the thermally treated products at $650-1000^{\circ} \mathrm{C}$ for $2 \mathrm{~h}$ in air and a water vapor atmosphere. Legend of pattern: $\mathrm{C}=$ calcite $\left(\mathrm{CaCO}_{3}\right) ; \mathrm{Ce}=$ Cebollite $\left(\mathrm{Ca}_{2} \mathrm{MgSi}_{2}(\mathrm{O}, \mathrm{OH})_{7}\right) ; \mathrm{Ch}=$ Chrysotile $\left(\mathrm{Mg}_{3} \mathrm{Si}_{2} \mathrm{O}_{5}(\mathrm{OH})_{4}\right)$; $\mathrm{L}=$ Lime $(\mathrm{CaO}) ; \mathrm{M}=$ Merwinite $\left(\mathrm{Ca}_{3} \mathrm{Mg}\left(\mathrm{SiO}_{4}\right)_{2}\right) ; \mathrm{P}=$ Portlandite $\left(\mathrm{Ca}(\mathrm{OH})_{2}\right) ; \mathrm{Q}=$ Quartz $\left(\mathrm{SiO}_{2}\right) ; \beta=\beta$-dicalcium silicate $\left(\mathrm{Ca}_{2} \mathrm{SiO}_{4}\right)$.

atmosphere by using a tubular furnace equipped with a water evaporator. For a water vapor atmosphere, distilled water was introduced at a flow rate of $2 \mathrm{~mL} / \mathrm{min}$ into the evaporator without a carrier gas to generate a $100 \%$ water vapor atmosphere in the furnace. The thermal decomposition in air was performed in stagnant condition in the same furnace by removing the evaporator.

After the thermal treatments of ACW18, the samples were ground for the successive analyses. Powder X-ray diffraction analyses (XRD; Rigaku Ultima IV, radiation $\mathrm{CuK} \alpha$, graphite monochromator, collecting step $0.02^{\circ}$, scanning speed $40^{\circ} / \mathrm{min}$, $2 \theta=10-80^{\circ}, 40 \mathrm{kV}, 20 \mathrm{~mA}$ ) were carried out to identify the crystalline phases before and after the thermal treatments. In addition, phase-contrast microscopic (PCM; Olympus BX51N-DPH) observation by using the immersion liquid with $n_{\mathrm{D}}{ }^{25^{\circ} \mathrm{C}}=1.550$ (Cargille) was carried out at 400 -fold magnification to count the number of chrysotile particles based on JIS A 1481:2006. ${ }^{13)}$ PCM analysis with the immersion liquid with $n_{\mathrm{D}}{ }^{25^{\circ} \mathrm{C}}=1.550$ shows that chrysotile fibers turn red-purple or blue in color. All PCM analyses were conducted on three specimens for each sample. According to the JIS A 1481:2006, when chrysotile particles (aspect ratio $\geq 3$ ) are observed more than three particles in 3000 particles of three specimens for each sample, the sample is defined as asbestos product. In other words, in the case of three or less chrysotile particles, the sample can be defined as non-asbestos product.

\section{Results and discussion}

\subsection{Thermal treatment of chrysotile-containing corrugated plate (ACW18)}

Figure 1 shows the XRD patterns of the products obtained by the thermal treatments of ACW18 at various temperatures for $2 \mathrm{~h}$ in air and a water vapor atmosphere. It was confirmed that XRD peaks of chrysotile in the samples were disappeared at $700^{\circ} \mathrm{C}$ in both atmospheres, though the peak intensity of chrysotile in the product treated at $650^{\circ} \mathrm{C}$ in a water vapor atmosphere was higher than that in air. Chrysotile decomposition can be expressed by following reactions: ${ }^{6), 18), 19)}$

$$
\begin{aligned}
& 2 \mathrm{Mg}_{3} \mathrm{Si}_{2} \mathrm{O}_{5}(\mathrm{OH})_{4} \rightarrow 3 \mathrm{Mg}_{2} \mathrm{SiO}_{4}+\mathrm{SiO}_{2}+4 \mathrm{H}_{2} \mathrm{O} \\
& \mathrm{Mg}_{2} \mathrm{SiO}_{4}+\mathrm{SiO}_{2} \rightarrow 2 \mathrm{MgSiO}_{3}
\end{aligned}
$$

The thermal decomposition of pure chrysotile involves dehydration and subsequent recrystallization leading to the formation of forsterite $\left(\mathrm{Mg}_{2} \mathrm{SiO}_{4}\right)$ and enstatite $\left(\mathrm{MgSiO}_{3}\right){ }^{18), 19)}$ However, forsterite or enstatite were not found in the products of ACW 18 treated at $700^{\circ} \mathrm{C}$. The products obtained at $700^{\circ} \mathrm{C}$ in air consisted of a low crystalline phase with a broad XRD peak ranging from 30 to $35^{\circ}$. With the increase in heating temperatures, the formation of lime $(\mathrm{CaO})$ and $\beta$-dicalcium silicate was clearly observed in air. After the thermal treatment at $1000^{\circ} \mathrm{C}$ in air, calcium magnesium silicates such as cebollite $\left(\mathrm{Ca}_{2} \mathrm{MgSi}_{2}(\mathrm{O}, \mathrm{OH})_{7}\right.$, JCPDS No. 43-1491) and merwinite $\left(\mathrm{Ca}_{3} \mathrm{Mg}\left(\mathrm{SiO}_{4}\right)_{2}\right.$, JCPDS No. 35-591) were detected as a minor phases. Since cebollite and merwinite contain magnesium, these minor phases would be formed by the solid-state reaction between lime and the decomposed products of chrysotile. Because of a natural mineral, the chemical composition of cebollite is indicated in the different ways such as $\mathrm{Ca}_{5} \mathrm{Al}_{2}$ $\mathrm{Si}_{3} \mathrm{O}_{12}(\mathrm{OH})_{4}, \mathrm{Ca}_{2}(\mathrm{Mg}, \mathrm{Fe}, \mathrm{Al}) \mathrm{Si}_{2}(\mathrm{O}, \mathrm{OH})_{7}$, or $\mathrm{Ca}_{2} \mathrm{MgSi}_{2}(\mathrm{O}, \mathrm{OH})_{7}$.

On the other hand, in a water vapor atmosphere, the thermal decomposition of calcite was accelerated by water vapor, and $\beta$-dicalcium silicate and calcium magnesium silicates were formed at lower temperatures. Calcite was almost decomposed at $650^{\circ} \mathrm{C}$ and portlandite $\left(\mathrm{Ca}(\mathrm{OH})_{2}\right)$ and $\beta$-dicalcium silicate were formed. Wang and Thomson ${ }^{20)}$ described that adsorbed water vapor weakened $\mathrm{Ca}-\mathrm{CO}_{3}$ bond and the thermal decomposition of calcite was accelerated by water vapor. Accelerated decomposition of calcite by water vapor leads to the formation of $\beta$-dicalcium silicate at lower temperatures by the solid-state reaction with silica. ${ }^{16)}$ The formation of portlandite is due to the hydration of lime during the cooling process of the products in a water vapor atmosphere. In addition, cebollite and merwinite were formed at $800^{\circ} \mathrm{C}$ in a water vapor atmosphere. These magnesium containing compounds were formed in a water vapor atmosphere at temperatures $200^{\circ} \mathrm{C}$ lower than in air. 
Table 1. Numbers of chrysotile particles detected by PCM in the thermally treated $\mathrm{ACW} 18$ at $600-1000^{\circ} \mathrm{C}$ for $2 \mathrm{~h}$ in air and a water vapor atmosphere

\begin{tabular}{ccc}
\hline \multirow{2}{*}{ Temperature $/{ }^{\circ} \mathrm{C}$} & \multicolumn{2}{c}{ ACW18 } \\
\cline { 2 - 3 } & Air & Water vapor \\
\hline 600 & + & + \\
650 & + & + \\
700 & 4 & 4 \\
800 & 5 & 0 \\
900 & 3 & 0 \\
1000 & 1 & 0 \\
\hline
\end{tabular}

+: Chrysotile fibers were clearly detected in the treated products.

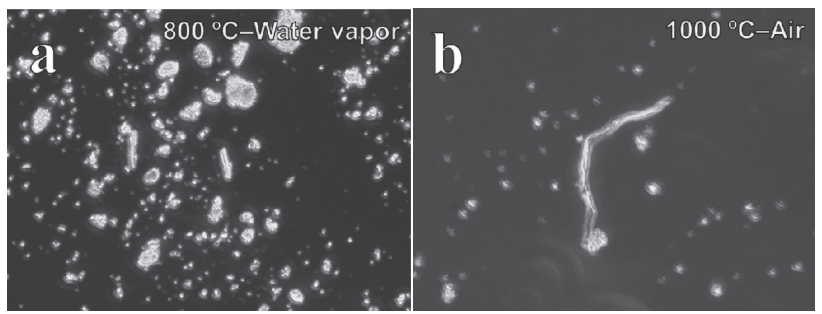

Fig. 2. PCM photographs of the ACW18 after thermal treatment at (a) $800^{\circ} \mathrm{C}$ and (b) $1000^{\circ} \mathrm{C}$ for $2 \mathrm{~h}$ in a water vapor atmosphere and in air, respectively.

\subsection{PCM results of thermally treated products}

Table 1 shows the numbers of chrysotile particles in ACW18 heated at $600-1000^{\circ} \mathrm{C}$ for $2 \mathrm{~h}$ in air and a water vapor atmosphere. In general, a large number of chrysotile particles were observed by PCM in the samples in which chrysotile was detected by XRD. Figure 2 shows the typical PCM photographs of the thermally treated products. As shown in Fig. 1, XRD peaks of chrysotile were disappeared by heating at $700^{\circ} \mathrm{C}$ in both atmospheres. However, four chrysotile particles were counted among 3000 particles in the products treated at $700^{\circ} \mathrm{C}$. When $\mathrm{ACW} 18$ was heated at $800^{\circ} \mathrm{C}$, five chrysotile particles were counted in the product obtained in air. In contrast, no chrysotile particle was detected in the product treated at $800^{\circ} \mathrm{C}$ in a water vapor atmosphere, as shown in Fig. 2a. Thus, the product treated at $800^{\circ} \mathrm{C}$ for $2 \mathrm{~h}$ in a water vapor atmosphere was determined to be a non-asbestos product. In air, the thermal treatment at $900^{\circ} \mathrm{C}$ was required to judge the product as non-asbestos for ACW18. However, one chrysotile particle was remained in the product even after the thermal treatment at $1000^{\circ} \mathrm{C}$ for $2 \mathrm{~h}$, as shown in Fig. 2b. Hashimoto et al. ${ }^{14)}$ also found that a small amounts of chrysotile particles were observed by direct PCM observation without grinding and sieving of the products obtained by heating pure chrysotile in air at $1000^{\circ} \mathrm{C}$ for $3 \mathrm{~h}$, and concluded that the insufficient heat transfer to the samples caused uncompleted decomposition of chrysotile.

According to the XRD results of the treated products (Fig. 1), the formation of calcium magnesium silicates by the solid-state reactions between decomposed products of chrysotile and cement components was accelerated by water vapor. Thus, ACWs were converted into non-asbestos products at lower temperatures in a water vapor atmosphere. It is noteworthy to point out that the products of ACWs after the thermal decomposition in a water vapor atmosphere mainly consisted of silicates. Therefore, this product can be safely recycled for the production of industrial materials.

\section{Conclusions}

The thermal decomposition of ACWs including 18 mass $\%$ chrysotile was conducted in air and a water vapor atmosphere and the treated products were analyzed by XRD and PCM based on JIS A 1481:2006. In a water vapor atmosphere, solid-state reactions between decomposed products of chrysotile and cement components were accelerated to form calcium magnesium silicates and ACWs were completely converted into non-asbestos products by thermal treatments at low temperatures below $800^{\circ} \mathrm{C}$ for $2 \mathrm{~h}$. Thermal decomposition technique of ACWs into nonasbestos products in a water vapor atmosphere may contribute to large-scale decomposition of ACWs with low energy consumption in comparison with the traditional melting method. In addition, the non-asbestos products obtained by this technique mainly consist of silicates and might be useful as raw materials to produce cements.

Acknowledgement This study was carried out as the "Development of Technology for the Safe Recovery and Treatment of Construction Materials Containing Asbestos" supported by New Energy and Industrial Technology Development Organization (NEDO) of Japan.

\section{References}

1) M. Fujishige, R. Sato, A. Kuribara, I. Karasawa and A. Kojima, J. Ceram. Soc. Japan, 114, 844-848 (2006).

2) M. Fujishige, R. Sato, A. Kuribara, I. Karasawa and A. Kojima, J. Ceram. Soc. Japan, 114, 1133-1137 (2006).

3) M. Fujishige, A. Kuribara, I. Karasawa and A. Kojima, J. Ceram. Soc. Japan, 115, 434-439 (2007).

4) K. Yanagisawa, T. Kozawa, A. Onda, M. Kanazawa, J. Shinohara, T. Takanami and M. Shiraishi, J. Hazard. Mater., 163, 593-599 (2009).

5) K. J. D. MacKenzie and R. H. Meinhold, Am. Mineral., 79, 43-50 (1994).

6) P. A. Candela, C. D. Crummett, D. J. Earnest, M. R. Frank and A. G. Wylie, Am. Mineral., 92, 1704-1713 (2007).

7) S. Hashimoto and A. Yamaguchi, J. Ceram. Soc. Japan, 113, 312-316 (2005).

8) S. Hashimoto, A. Yamaguchi, S. Honda, H. Awaji and K. Fukuda, J. Ceram. Soc. Japan, 113, 804-807 (2005).

9) S. Hashimoto, H. Takeda, A. Okuda, A. Kambayashi, S. Honda, H. Awaji and K. Fukuda, J. Ceram. Soc. Japan, 115, 290-293 (2007).

10) S. Hashimoto, A. Okuda, A. Kambayashi, S. Honda, H Awaji and K. Fukuda, J. Ceram. Soc. Japan, 114, 1150-1154 (2006).

11) H. Takeda, S. Hashimoto, A. Okuda, S. Honda, H. Awaji and K. Fukuda, J. Ceram. Soc. Japan, 115, 562-566 (2007).

12) S. Hashimoto, H. Takeda, A. Okuda, A. Kambayashi, S. Honda, Y. Iwamoto and K. Fukuda, J. Ceram. Soc. Japan, 116, 242-246 (2008).

13) Japanese Standards Association, Determination of asbestos in building material products, JIS A 1481, 2006.

14) S. Hashimoto, A. Okuda, A. Kambayashi, S. Honda, H. Awaji and K. Fukuda, J. Ceram. Soc. Japan, 114, 716-718 (2006).

15) A. F. Gualtieri, C. Cavenati, I. Zanatto, M. Meloni, G. Elmi and M. Lassinantti Gualtieri, J. Hazard. Mater., 152, 563-570 (2008).

16) T. Kozawa, A. Onda and K. Yanagisawa, Chem. Lett., 38, 476477 (2009).

17) T. Kozawa, A. Onda and K. Yanagisawa, J. Eur. Ceram. Soc., 29, 3259-3264 (2009)

18) H. De, S. Santos and K. Yada, Clays Clay Miner., 27, 161-174 (1979).

19) A. Cattaneo, A. F. Gualtieri and G. Artioli, Phys. Chem. Miner., 30, 177-183 (2003)

20) Y. Wang and W. J. Thomson, Chem. Eng. Sci., 50, 1373-1382 (1995). 